\title{
Runoff Harvesting and Storage for Rice Crop at Hamelmalo, Semiarid Region of Eritrea
}

\author{
Ramesh Prasad Tripathi*, Woldeselassie Ogbazghi, Semere Amlsom, Simon Measho \\ Department of Land Resources and Environment, Hamelmalo Agricultural College, Keren, Eritrea \\ Email: "rp.tripathi52@gmail.com,wogbazghi@gmail.com, semereamlesom@gmail.com, \\ simonmeasho@gmail.com
}

Received 15 September 2015; accepted 27 November 2015; published 1 December 2015

Copyright (C) 2016 by authors and Scientific Research Publishing Inc.

This work is licensed under the Creative Commons Attribution International License (CC BY). http://creativecommons.org/licenses/by/4.0/

(c) () D Den Access

\section{Abstract}

Rice is staple food in Eritrea but it is not cultivated in the country due to semiarid conditions. However, possibilities exist for growing rice using runoff produced from nonagricultural hilly lands, which occupy $>50 \%-80 \%$ area of all agricultural watersheds in Eritrea. Study was undertaken in 6 ha watershed at Hamelmalo to design and develop waterway for safe harvesting of runoff from 5.5 ha catchment into a pond for facilitating runoff farming of rice in 0.5 ha field at the outlet end receiving recurrent floods. Slope of the catchment ranged from $1 \%$ to $6 \%$. The waterway was designed to intercept and carry runoff from two major drains in nonagricultural land together and delivering into a pond made adjacent to rice field. The waterway was about $323 \mathrm{~m}$ long with $3 \mathrm{~m}$ top width, $1.5 \mathrm{~m}$ bottom width and $0.3-0.8 \mathrm{~m}$ depth from surface. The pond was $60 \mathrm{~m}$ long, $9 \mathrm{~m}$ wide and $1 \mathrm{~m}$ deep with $1.5 \mathrm{~m}$ high earthen dam towards rice field using soil excavated from the pond. Embankment on the remaining sides was mango orchard land slopping towards pond. The dam base width was $4 \mathrm{~m}$, top width was $2.5 \mathrm{~m}$ and height was $1.5 \mathrm{~m}$ from the ground surface. Two spill ways were provided in the dam at ends at the ground level to facilitate release of runoff from the pond for irrigation. Gross capacity of pond was $>1000 \mathrm{~m}^{3}$. Combined effect of river water, percolation from pond and wetter rice field raised groundwater table from $3.25 \mathrm{~m}$ depth in June to $1.4 \mathrm{~m}$ by mid-crop season. This resulted in soil wetness exceeding field capacity below 0.7 $\mathrm{m}$ depth and greener crop. Rice yields exceeding $2000 \mathrm{~kg} \cdot \mathrm{ha}^{-1}$ were harvested under runoff farming conditions. Soil puddling was more conducive to rice crop than compaction under available soil and water resources.

\section{Keywords}

Compaction, Pond, Puddling, Rice, Runoff Farming, Waterway

\footnotetext{
${ }^{*}$ Corresponding author.

How to cite this paper: Tripathi, R.P., Ogbazghi, W., Amlsom, S. and Measho, S. (2016) Runoff Harvesting and Storage for Rice Crop at Hamelmalo, Semiarid Region of Eritrea. Computational Water, Energy, and Environmental Engineering, 5, 1-9. http://dx.doi.org/10.4236/cweee.2016.51001
} 


\section{Introduction}

Rice is not a semiarid region crop because of its high water requirements. However, in Eritrea significant runoff produced from nonagricultural lands, which occupy $>50 \%-80 \%$ area of all agricultural watersheds, can be harvested and used as additional rainwater to facilitate rice farming [1]-[3]. Farmers cultivate crops on un-terraced sloppy lands that also contribute $60 \%-70 \%$ of rainfall as runoff [2] [4], which flows forming numerous channels and gullies damaging downstream field crops. In watersheds of size more than 5 ha, runoff frequently floods the downstream fields at the outlet rendering them unfit for raising a good crop during rainy season [3]. The same runoff could be boon to rice production if diverted through designed waterways into small ponds constructed on upstream side of such fields [3]. Crop yields in Eritrea are low $\left(<0.2-0.6 \mathrm{t}^{\mathrm{t}} \mathrm{ha}^{-1}\right)$ because $>70 \%$ of the total rainfall is lost as runoff from traditional sloppy fields [1] [2] [5]. Storage of even part of the runoff in watersheds, which is also rich in nutrients and soil colloidal fractions, can serve as not only extra rainwater but also nutrients for crops [3] [6]-[8]. Rice cultivation through water harvesting in terraced fields was successfully demonstrated in Uganda [9]. Although rice likes wetter regime in the root zone, irrigations applied at 8 days interval were also optimum for rice growth in Sudan [10].

Rice needs water to meet its evapotranspiration (ET) requirements and to satisfy percolation from the soil moisture regime of field capacity to submergence necessary for optimum yields [11] [12]. High percolation from rice fields and ponds made for harvesting runoff to meet water requirements of rice will also recharge ground water table that may serve as source of sub-irrigation directly into the crop root zone [3] [13]. Tesfamichael [14] observed development of water table that fluctuated from 0.4 - $1.2 \mathrm{~m}$ depth from surface during October 2006 to March 2007 in about 6 ha valley farmland in Akriya, Asmara region of Eritrea, surrounded by 36.5 ha hilly terrain. Contribution of groundwater table to ET requirements of wheat was $90 \%$ from the water table fluctuating from $0.4-0.55 \mathrm{~m}$ depth from surface, which declined to $38 \%$ as water table dropped to $1.2 \mathrm{~m}$ depth by milk stage [14].

Runoff farming has been traditionally practiced as spate irrigation in Eritrea since more than 100 years ago [7]. Spate irrigation is a pre-planting system of irrigation by diverting seasonal rivers producing flash floods from highlands and mountainous areas to recharge soil profile in the lowlands. More than $50 \%$ of total irrigation in Eritrea is through spate irrigation practiced from eastern to western lowlands along the Red sea coast [15] [16]. Depending upon rainfall, catchment size and runoff from highlands, diversion dams are constructed in the rivers to channelize runoff into cultivated fields to recharge soil profile in several flash floods before planting a crop. Water use efficiency of spate irrigation systems in Eritrea has been low due to wild flooding of uncropped fields leading to over or inadequate watering [7] [16]. All spate irrigated fields in Eritrea could prove boon to rice production with high water use efficiency through improvements in existing diversion structures to regulate flood water supply and field level management. Rice could be grown during preplanting irrigation period from the third week of June to October with little intervention in the existing cropping system and flood water management. Objective of this study was to design and develop runoff harvesting system in agricultural watersheds associated with nonagricultural lands to facilitate runoff farming of rice in semiarid environments of Hamelmalo, Anseba region of Eritrea.

\section{Materials and Methods}

Study was undertaken in 2013 and 2014 in a 6 ha partly cultivated watershed at Hamelmalo Agricultural College $\left(15^{\circ} 52^{\prime} 20.6^{\prime \prime} \mathrm{N}\right.$ and $38^{\circ} 27^{\prime} 57.6^{\prime \prime} \mathrm{E}$ at $1280 \mathrm{msl}$ ), located in the semiarid region of Eritrea. Annual rainfall in the past seven years ranged from 370 - $663.1 \mathrm{~mm}$ with a mean of $488 \mathrm{~mm}$ and average annual pan evaporation of $1931 \mathrm{~mm}$. Highest mean monthly temperature occurred in May $\left(35.7^{\circ} \mathrm{C}\right)$ and lowest in January $\left(11.1^{\circ} \mathrm{C}\right)$. Total rainfall was $388 \mathrm{~mm}$ in 2013 and $429 \mathrm{~mm}$ in 2014 (Figure 1). Monsoon season in the two cropping years started from third week of June and ended by third week of September. Highest storm rainfall was $57.7 \mathrm{~mm}$ in July, 2013 and $48.5 \mathrm{~mm}$ in September, 2014.

\subsection{Watershed Characteristics}

The watershed land was surveyed using total station and GPS to determine slope, contour lines, ridge lines, boundary, area and location of natural drains. About 2.5 ha watershed land was cultivated and was on the downstream side and 3.5 ha uncultivated. The uncultivated land comprised of wild bushes and trees, dominated by 


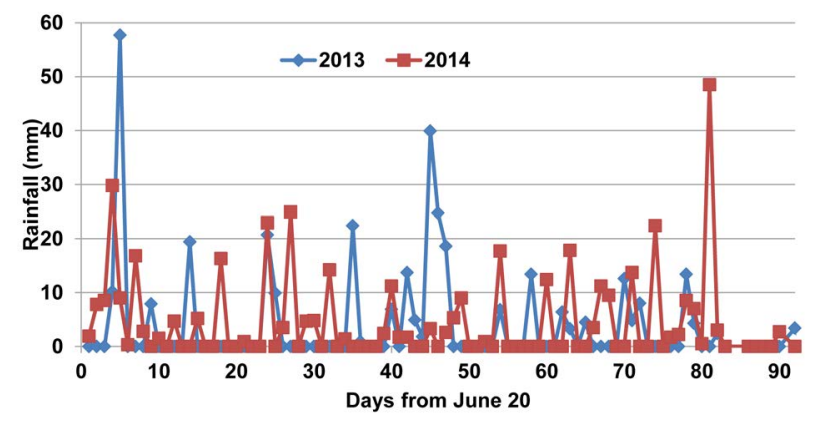

Figure 1. Rainfall during the crop season of 2013 and 2014.

Acacia and Zizyphus species and 4 buildings, each having cemented plan area of $800 \mathrm{~m}^{2}$, together with an old mango orchard and a small building $\left(40 \mathrm{~m}^{2}\right)$ adjacent to the selected rice field. Runoff from buildings was $100 \%$ of the rainfall. Soil texture was stony sandy loam in uncultivated portion, sandy loam in cultivated portion and loam in the rice field. Slope of the catchment contributing runoff for use by rice crop ranged from $1 \%-6 \%$ and that of rice field was $<1 \%$. Average bulk density of soil was $1.69 \mathrm{Mg} \cdot \mathrm{m}^{-3}$ in the uncultivated field and $1.4 \mathrm{Mg}$ $\mathrm{m}^{-3}$ in the rice field. Presence of stones, beating action of raindrops and trampling by grazing animals over the years increased density of the uncultivated land. Two major drains were carrying runoff from uncultivated land on the upstream and leading to gully formation in downstream cropped fields before entering into Anseba river through the selected rice field. Anseba river is normally dry but flows whenever rainfall occurs in its catchment.

\subsection{Design Considerations}

Waterway was designed to intercept and carry runoff from the two drains of the uncultivated land together about $3 \mathrm{~m}$ upstream of the cultivated land into a pond constructed adjacent to the rice field (Figure 2). The two drains at the junction of cultivated and uncultivated lands were about $10 \mathrm{~m}$ wide and $40 \mathrm{~m}$ apart. Slope of the land, about $3 \mathrm{~m}$ upstream from the cultivated land, was $<1 \%-1.5 \%$. The waterway was thus proposed from $3 \mathrm{~m}$ on upstream side of the cultivated land running about $50 \mathrm{~m}$ across the slope dividing the cultivated and uncultivated land before turning downslope towards the pond. Minor bending was allowed to accommodate local land surface conditions. To ensure non-erosive velocity of flow, channel bed slope was maintained zero by providing successive drops in bed level at the points of sudden change in slope. Equation (1) guided vertical interval between the successive channels [17].

$$
\mathrm{VI}=0.12 \mathrm{~s}+0.3
$$

where VI is vertical interval $(\mathrm{m})$ between channel beds, and $\mathrm{s}$ is per cent slope.

Flow in the waterway between successive drops was due to hydraulic gradient established by runoff. Length of each level section of the waterway and drop height was variable. Stones and gravels were placed at the drop section of the waterway to reduce scouring. Due to lack of data on rainfall intensity and duration, waterway and pond dimensions were decided from rainfall-runoff relationship developed from measurements made in another 4.29 ha model watershed at Hamelmalo farm under similar soil and vegetation conditions [2] and peak storm rainfall in the last 10 years. Peak storm rainfall in 2010 at Hamelmalo was $77.2 \mathrm{~mm}$, therefore, waterway and pond were designed for the runoff that can be produced from a peak storm rainfall of $80 \mathrm{~mm}$. Most storm rainfall amounts in the area are $<30 \mathrm{~mm}$. Following was the rainfall-runoff relationship on $3 \%$ slope used in the design.

$$
\text { Runoff }=0.52 \times \text { rainfall }-2.0 \text {, }
$$

Both rainfall and runoff are in $\mathrm{mm}$. The waterway length was $323 \mathrm{~m}$, top width $3 \mathrm{~m}$, bottom width $1.5 \mathrm{~m}$ and depth 0.3 - $0.8 \mathrm{~m}$ from surface. The pond length was $60 \mathrm{~m}$, width $9 \mathrm{~m}$ and depth $1 \mathrm{~m}$ with $1.5 \mathrm{~m}$ high earthen dam on the downstream side adjacent to the rice field. Soil excavated from the pond was acceptable for construction of the dam. Embankment on the other three sides was not disturbed to allow natural local inflow of runoff from the adjoining mango orchard. Base width of the dam was $4 \mathrm{~m}$, top width $2.5 \mathrm{~m}$ and height $1.5 \mathrm{~m}$ from the ground surface. Top width of $2.5 \mathrm{~m}$ was to facilitate thorough passage of farm machineries and ensure stability of the dam. Provision of two spill ways was made at ends of the dam at the ground level to allow irrigation 


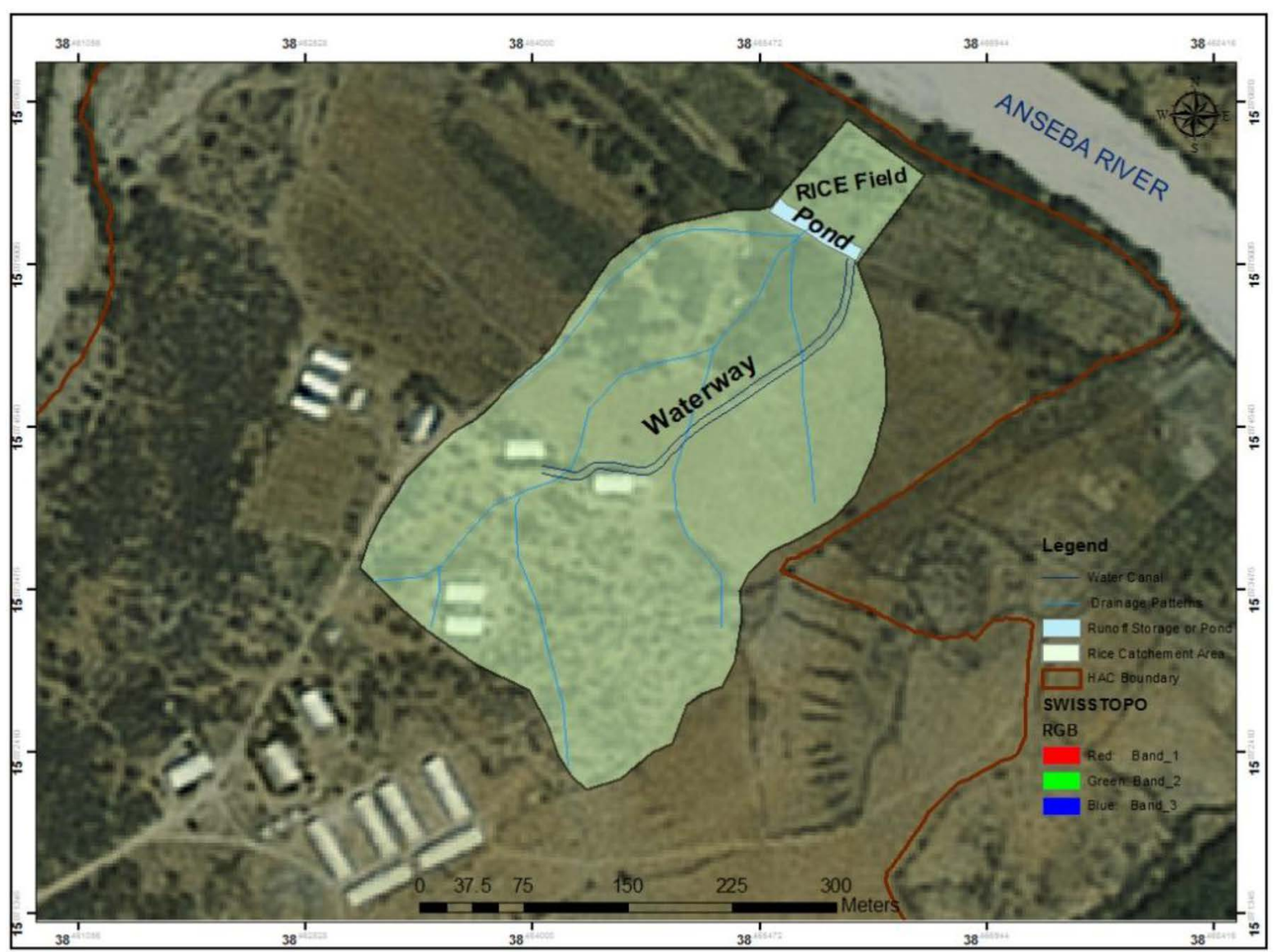

Figure 2. Rice field and catchment area contributing runoff.

and release of extra runoff from the pond. Gross capacity of the pond was $>1000 \mathrm{~m}^{3}$. Location of buildings, natural drains, Anseba River, rice field and designed waterway can be seen in Figure 2.

\subsection{Crop Response Evaluation}

Effect of water harvesting on runoff farming of rice was evaluated through field experiments in 2013 and 2014. Since percolation is a major water management problem in rice farming, emphasis on treatment selections was to optimize level of soil puddling or compaction done to control percolation without affecting rice growth. Rice variety NERICA 4 was transplanted at 5 levels of puddling and 5 levels of compaction. Rice seedlings were raised 21 days before transplanting in the field. Puddling treatments were no puddling $\left(\mathrm{T}_{0}\right)$, puddling by one $\left(\mathrm{T}_{1}\right)$, two $\left(T_{2}\right)$, three $\left(T_{3}\right)$ and four $\left(T_{4}\right)$ passes of puddler replicated 4 times [18]. To simulate puddling by local bullock drawn plough, wet tillage in the plots was done manually by spade followed by churning-cum-leveling by small wooden plank. Soil compaction treatments were no compaction $\left(T_{0}\right)$, compaction by one $\left(T_{1}\right)$, two $\left(T_{2}\right)$, three $\left(T_{3}\right)$ and four $\left(T_{4}\right)$ passes of $600 \mathrm{~kg}$ tractor driven roller in 4 replications [19]. Both the experiments were separately laid out in complete randomized block design. Irrigations were given to maintain 20 - $50 \mathrm{~mm}$ submergence for 10 days for seedling establishment after transplanting in puddled and compacted fields. Fertilizer nutrients applied were $120 \mathrm{~kg} \mathrm{~N}$ and $46 \mathrm{~kg} \mathrm{P} \mathrm{ha}^{-1}$ through urea and DAP. Entire DAP was applied as basal dose during last puddling operation and remaining $\mathrm{N}$ was applied through urea in two equal splits at 20 days interval from transplanting. Rice is normally broadcasted under rainfed farming but transplanting was preferred to shorten crop duration in the field by raising nursery 21 days before commencement of the monsoon. After cessation of rainfall in September, water requirement of rice was much higher than $120 \mathrm{~mm}$ irrigation applied in $6 \mathrm{~m}$ $\times 1 \mathrm{~m}$ nursery plots. Submergence by rainfall or runoff was allowed to a maximum of $0.1 \mathrm{~m}$. Results of 2013 experiment showed superiority of puddling on crop performance and, therefore, only puddling experiment was repeated in 2014. 


\section{Results and Discussion}

\subsection{Construction of Waterway and Pond}

As per design, waterway was constructed to intercept and carry runoff from $3 \mathrm{~m}$ upstream of the cultivated land, running $50 \mathrm{~m}$ across the slope with minor bending to accommodate local land surface situations before turning downslope towards the pond (Figure 3). The waterway downslope followed one of the drains almost centrally dividing the lower catchment. Soil excavated from the first $50 \mathrm{~m}$ waterway running across the slope was placed only on the downstream side of the embankment (Figure 3). Embankment on the upstream was natural ground level to facilitate runoff interception. However, embankments were formed on both sides after turning downslope until next $120 \mathrm{~m}$. Thereafter slope of the cultivated land on the right side was perpendicular to the waterway and, therefore, embankment was again made only on the left bank to facilitate direct runoff interception from the right side. The waterway depth was varying with slope. Entire runoff from the cultivated land joined the waterway in its lower $1 / 4$ section. Provision for inflow of runoff from left side of the waterway was also made at appropriate locations.

The pond of designed size $(60 \mathrm{~m} \times 9 \mathrm{~m} \times 1 \mathrm{~m})$ was constructed adjacent to rice field on the upstream side. Pond embankment (dam) adjacent to rice field was of base width $4 \mathrm{~m}$, top width $2.5 \mathrm{~m}$ and height $1.5 \mathrm{~m}$ from ground surface. The remaining 3 sides were undisturbed mango orchard land sloping towards the pond, which facilitated not only direct inflow of local runoff into the pond but also increased pond capacity with rising water level above the land surface. Soil excavated from the pond was used for construction of the dam after removing gravels and stones. Two orifices of diameter $0.125 \mathrm{~m}$ were installed at ends of the dam for safe release of excess runoff from pond into $1 \mathrm{~m}$ wide (base width) field channel constructed on the two sides of the rice field. The dam was repeatedly compacted by moving a $600 \mathrm{~kg}$ tractor driven roller. Thorough passage of tractor and human traffic was allowed over the dam for its safety and proper use of the farmland. Entire work was done manually by students (Figure 4). In case of emergency, provision for natural spillway was also made on eastern side of the embankment from where overflowing runoff could be diverted into another safety channel of $1.5 \mathrm{~m}$ base width made along irrigation channel in the rice field. Natural inflow of runoff from sides was also intercepted

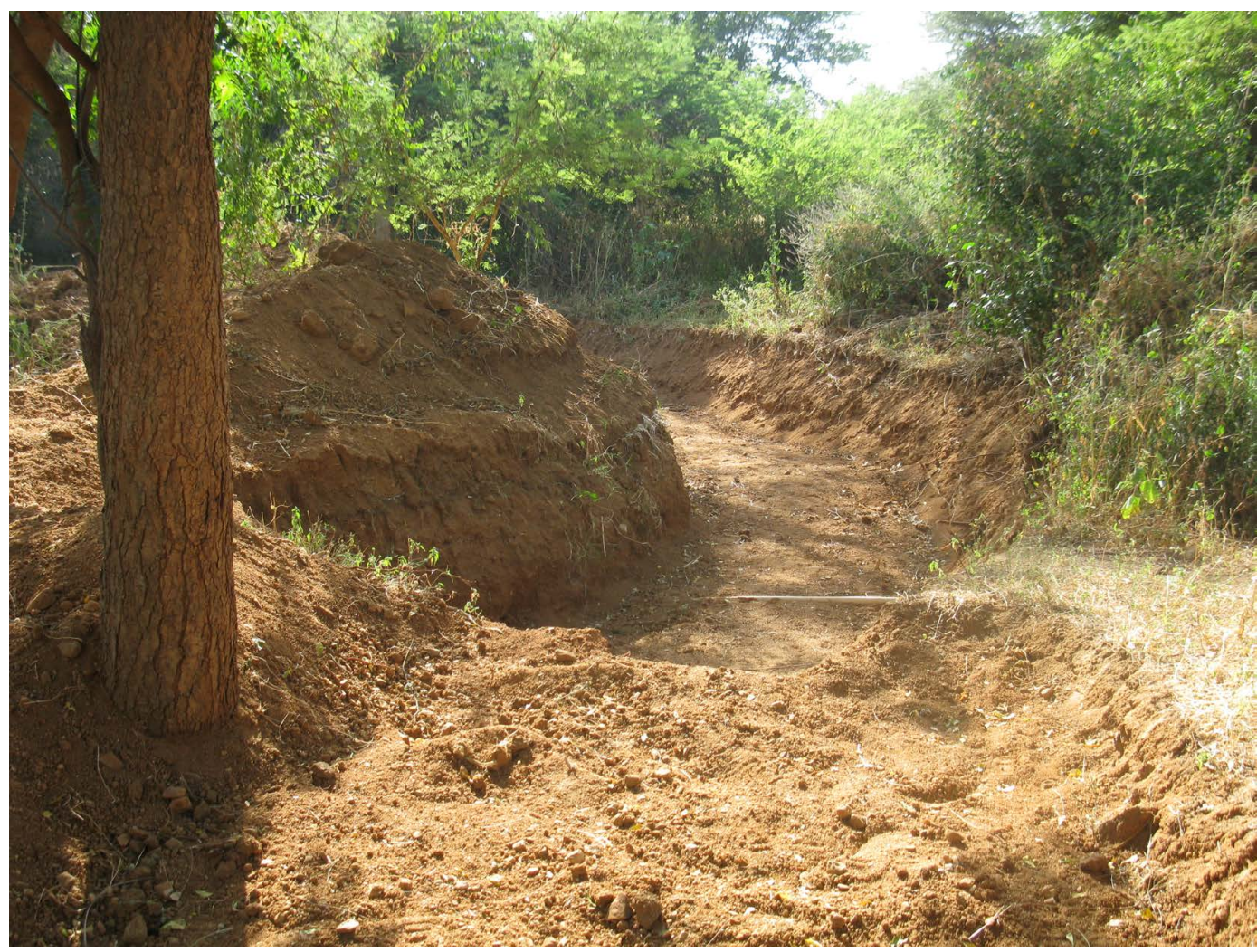

Figure 3. Waterway to intercept runoff. 


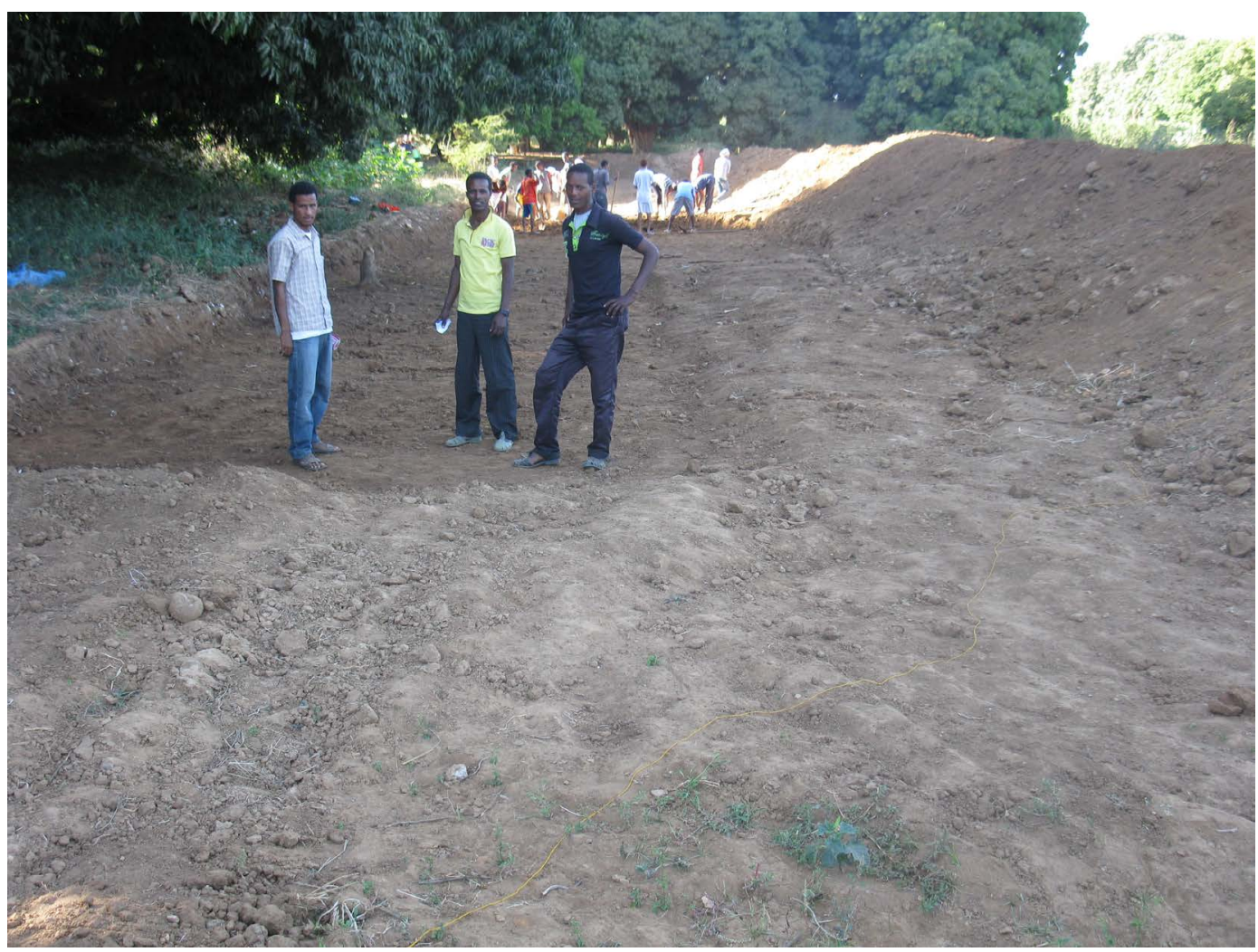

Figure 4. Students digging the pond.

and stored in this safety channel before allowing into irrigation channels or rice plots.

\subsection{Performance of Waterway and Pond}

The waterway has been performing well for the last 3 years. Soil texture of the rice field was slowly transforming from loam to sandy loam and loamy sand in lower depths below $0.8-1 \mathrm{~m}$. Pond was thus draining quickly after every rainfall. In 2013, pond received runoff to almost its full capacity twice but in 2014, it received only once due to lower storm rainfall. However, waterway, pond and rice field channels assured additional water availability to the crop and zero runoff from the watershed. The incoming colloidal sediments with runoff in the pond are expected to clog soil pores with time allowing water to stay for longer time. Part of the sediments received in the pond could also be used as manure in the rice field or elsewhere as necessary.

\subsection{Development of Water Table and Soil Wetness}

Seepage from Anseba river, runoff stored in the pond and irrigation channels and wetness in the rice plots raised groundwater table in the rice field from $3.25 \mathrm{~m}$ depth in June end to $1.4 \mathrm{~m}$ by $4^{\text {th }}$ week of August, which receded down to $1.7 \mathrm{~m}$ by crop maturity (Figure 5). Rate of rise of water table was faster than receding. The water table rose by $1.85 \mathrm{~m}$ in about 48 days but receded only $0.3 \mathrm{~m}$ in next 75 days. The water table was oscillating within $1.5 \pm 0.1 \mathrm{~m}$ for about 2 months during grand growth to reproductive stages of rice crop.

The shallow groundwater table greatly affected wetness in the root zone. Soil water content in the third week of September showed upward gradient (Figure 6). Whereas surface soil was dry forming cracks, soil wetness below $0.7 \mathrm{~m}$ depth was near field capacity and was increasing with depth (Figure 6). Roots of NERICA rice were observed down to $0.8 \mathrm{~m}$ [3] and, therefore, parts of the rice roots were receiving water by capillarity from the fluctuating water table and the crop was greener until October (Figure 7). The rising groundwater table due to combined effect of water level in the river and percolation from the pond and rice field may serve as a natural source of sub-irrigation to the rice crop. The crop was harvested in November first week. 


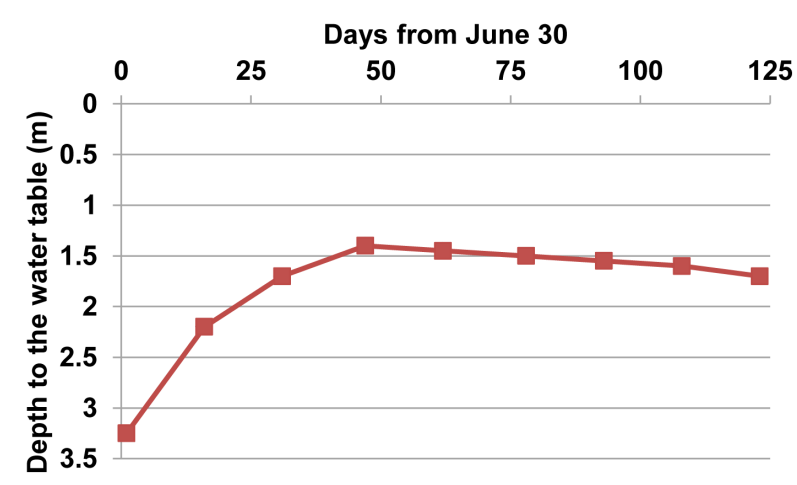

Figure 5. Two-year average water table fluctuation during the crop season.

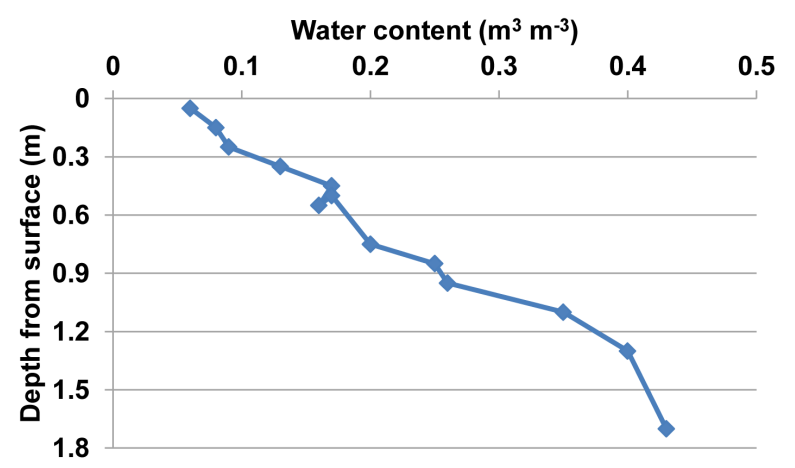

Figure 6. Soil moisture profile in the rice field.

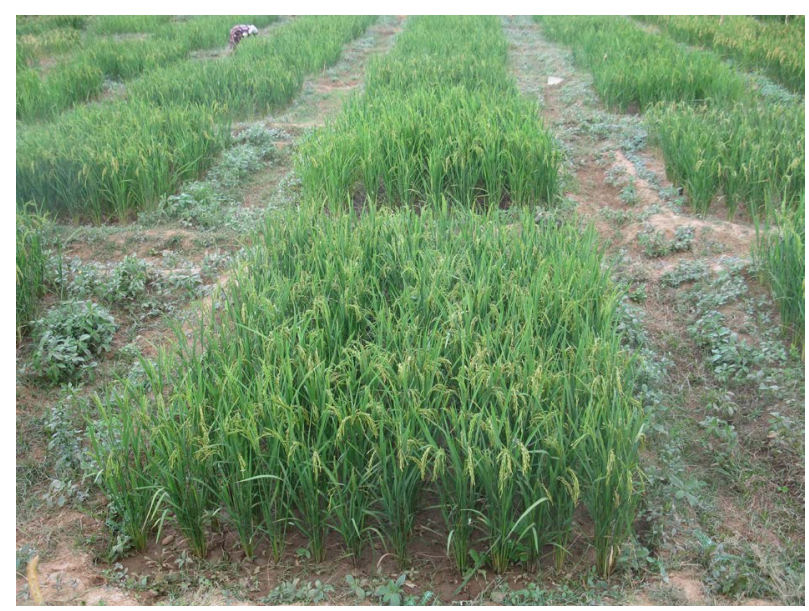

Figure 7. Rice experimental crop on October 25, 2014.

\subsection{Performance of Rainfed Rice}

Rice yields in 2013 ranged from $782 \mathrm{~kg} \cdot \mathrm{ha}^{-1}$ under no puddling to $2307 \mathrm{~kg} \cdot \mathrm{ha}^{-1}$ under 4 puddlings (Table 1). Effect of 2 or 4 puddlings was statistically equal on crop performance. In 2014, yields increased from 850 $\mathrm{kg} \cdot \mathrm{ha}^{-1}$ under no puddling to $2438 \mathrm{~kg} \cdot \mathrm{ha}^{-1}$ under 2 puddlings. Yields in second year were also at par under 2 and 4 puddlings. Results thus show that 2 puddling operations by country plow would be sufficient for optimum rice yields in the loam soil of Hamelmalo under runoff farming. Similarly compaction, which had similar effect on percolation, improved rice yields from $690 \mathrm{~kg} \cdot \mathrm{ha}^{-1}$ under no compaction to $1980 \mathrm{~kg} \cdot \mathrm{ha}^{-1}$ under compaction by 4 passes of $600 \mathrm{~kg}$ roller. Yields were at par under 2 and 4 passes of roller. Results show that puddling was superior 
Table 1. Effect of puddling and compaction on grain yield of NERICA 4 rice.

\begin{tabular}{ccccc}
\hline $\begin{array}{c}\text { Puddling by } \\
\text { spade }\end{array}$ & $\begin{array}{c}\text { Grain yield in } \\
2013\left(\mathrm{~kg} \cdot \mathrm{ha}^{-1}\right)\end{array}$ & $\begin{array}{c}\text { Grain yield in } \\
2014\left(\mathrm{~kg} \cdot \mathrm{ha}^{-1}\right)\end{array}$ & $\begin{array}{c}\text { Compaction by } 600 \mathrm{~kg} \text { roller } \\
\text { Grain yield in } 2013 \\
\left.\text { (kg.ha }^{-1}\right)\end{array}$ \\
\hline $\mathrm{T}_{0}$ (No puddling) & 782 & 850 & $\mathrm{~T}_{0}$ (no compaction) & 690 \\
$\mathrm{~T}_{1}$ (1 puddling) & 1181 & 1488 & $\mathrm{~T}_{1}$ (1 pass roller) & 1234 \\
$\mathrm{~T}_{2}$ (2 puddling) & 1811 & 2438 & $\mathrm{~T}_{2}$ (2 pass roller) & 1430 \\
$\mathrm{~T}_{3}$ (3 puddling) & 1921 & 2313 & $\mathrm{~T}_{3}$ (3 pass roller) & 1550 \\
$\mathrm{~T}_{4}$ (4 puddling) & 2307 & 2063 & $\mathrm{~T}_{4}$ (4 pass roller) & 1980 \\
Mean & 1600 & 1830 & Mean & 1369 \\
LSD at $5 \%$ & 552 & 572 & LSD at 5\% & 605 \\
\hline
\end{tabular}

to compaction in terms of crop performance under runoff farming conditions of Hamelmalo. These yields are as against highly poor sorghum stands due to recurrent floods and consequent wetness and deposition of eroded materials in such fields. Since successful rice crop has been harvested for the first time in Eritrea under runoff farming conditions more multilocational trails are necessary to optimize soil, water and nutrient requirements in addition to development of less than 4 month duration NERICA varieties suitable for different rainwater management conditions.

\section{Conclusions}

1) Water harvested from $>50 \%-80 \%$ nonagricultural lands of all agricultural watersheds in Eritrea can significantly meet water requirements of rice.

2) Earthen waterway and pond constructed to harvest runoff would be viable in arresting further land degradation.

3) Rice yields exceeding $2000 \mathrm{~kg} \cdot \mathrm{ha}^{-1}$ could be harvested under runoff farming conditions.

4) Soil puddling twice by local plow would be better option in loam soil but it should be verified for coarser texture soils.

5) River or any natural drain on the downstream rice field and upstream pond could raise groundwater table significantly to serve as source of sub-irrigation directly into root zone.

6) Efforts on rice cultivation could save hard currency to import rice for local consumption.

\section{Acknowledgements}

Authors are grateful to UNDP for providing funds from SGP/GEF grant for carrying out this research and to Mr. Tseneo Tsrusaki, Japanese International Cooperation Agency for supplying NERICA rice seed.

\section{References}

[1] MOA (Ministry of Agriculture) (2005) Area and Production by Zoba from 1992-2005. MOA, Asmara, Eritrea.

[2] Tripathi, R.P. and Ogbazghi, W. (2010) Development and Management of a Hilly Watershed in Hamelmalo Agricultural College farm, as a Demonstration Site for Farmers and a Study Site for Students. Final Technical Report of the Project Financed by Eastern and Southern Africa Partnership Programme (ESAAP), Department of Land Resources and Environment, Hamelmalo Agricultural College, Keren, Eritrea, 59 p.

[3] Tripathi, R.P., Ogbazghi, W., Amlesom, S. and Araia, W. (2014) Optimizing Tillage and Rain Water Conservation in the Soils of Hamelmalo Region of Eritrea for Arresting Soil Degradation and Achieving Sustainable High Crop Yields. Final Technical Report of the Project Financed by GEF/SGP, UNDP, Department of Land Resources and Environment, Hamelmalo Agricultural College, Keren, Eritrea, 112 p.

[4] Temesgen, M., Rockstrom J., Savenije, H.H.C., Hoogmoed, W.B. and Alemu, D. (2008) Determination of Tillage Frequency among Smallholder Farmers in Two Semiarid Areas in Ethiopia. Physics and Chemistry of the Earth, 33, 183-191. http://dx.doi.org/10.1016/j.pce.2007.04.012

[5] FAO (2005) Global Information and Early Warning System on Food and Agriculture World Food Programme. Special report FAO/WFP Crop and Food Supply Assessment Mission to Eritrea. FAO, Rome. 
[6] Elwell, H.A. and Stocking, M.A. (1988) Loss of Soil Nutrients by Sheet Erosion Is a Major Hidden Farming Cost. The Zimbabwe Science News, 22, 79-82.

[7] Tesfai, M. (2001) Soil and Water Management in Spate Iirrigation Systems in Eritrea. Ph.D. Thesis, Department of Erosion and Soil and Water Conservation, Wageningen University and Research Center, The Netherlands, 211 p.

[8] Ashouri, M. (2012) The Effect of Water Saving Irrigation and Nitrogen Fertilizer on Rice Production in Paddy Fields of Iran. International Journal of Bioscience, Biochemistry and Bioinformatics, 2, 56-59. http://dx.doi.org/10.7763/IJBBB.2012.V2.70

[9] Goto, A., Nishimaki, R., Suzuki, S., Watanabe, F. and Takahashi, S. (2012) Terrace Development Applied as a Water Harvesting Technology for Stable NERICA Production in Uganda. Journal of Arid Land Studies, 22, 243-246.

[10] Abu, S.T. and Malgwi, W.B. (2012) Effects of Irrigation Regime and Frequency on Soil Physical Quality, Water Use Efficiency, Water Productivity and Economic Returns of Paddy Rice. ARPN Journal of Agricultural and Biological Science, 7, 86-99.

[11] Tripathi, R.P., Kushwaha, H.S. and Mishra, R.K. (1986) Irrigation Requirement of Rice under Shallow Water Table Conditions. Agricultural Water Management, 12, 127-136. http://dx.doi.org/10.1016/0378-3774(86)90011-9

[12] Bajpai, R.K. and Tripathi, R.P. (2000) Evaluation of Non-Puddling under Shallow Water Tables and Alternative Tillage Methods on Soil and Crop Parameters in a Rice-Wheat System in Uttar Pradesh. Soil and Tillage Research, 55, 99-106. http://dx.doi.org/10.1016/S0167-1987(00)00111-2

[13] Tripathi, R.P., Kushwaha, H.S. and Agrawal, A. (1987) A Simple Non-Weighing LysimeterInstallation with Rain Shelter. Agricultural and Forest Meteorology, 41, 275-288. http://dx.doi.org/10.1016/0168-1923(87)90084-0

[14] Tesfamichael, F. (2007) Integrated Effect of Irrigation and Nitrogen on Wheat Productivity under Shallow Water Table Condition in Eritrea. M.Sc. Thesis, Department of Land Resources and Environment, Hamelmalo Agricultural College, Eritrea, $91 \mathrm{p}$.

[15] Tesfai, M. and Stroosnijder, L. (2000) The Eritrean Spate Irrigation System. Agricultural Water Management, 48, 512-560.

[16] Amlesom, S. (2005) Review of Irrigation Development in Eritrea. In: Mehari, T. and Ghebru, B., Eds., Irrigation Development in Eritrea: Potentials and Constraints, Proceedings of the Workshop of the Association of Eritreans in Agricultural Sciences (AEAS) and the Sustainable Land Management Programme (SLM), Eritrea, 14-15 August 2003, 5-11.

[17] Abraham, K., Dawit, F., Kibrom, B., Natsnet, O. and Selemawit, W. (2014) Effect of Puddling on Soil Properties and Yield of Rice. Senior Research Project, Department of Land Resources and Environment, Hamelmalo Agricultural College, Eritrea, 40 p.

[18] Asmelash, M., Filmon, D., Amanuel, G., Selam, E. and Natsnet, K. (2014) Effect of Compaction on Soil Properties and Yield of Rice. Senior Reseach Project, Department of Land Resources and Environment, Hamelmalo Agricultural College, Eritrea, 50 p.

[19] ASAE (American Society of Agricultural Engineers) (1989) Design, Layout, Construction and Maintenance of Terrace Systems. ASAE Standard S268.3, St. Joseph, MI. 